\title{
PENGARUH PEMBERIAN KEGIATAN OLAHRAGA AEROBIK TERHADAP PENURUNAN TEKANAN DARAH PADA REMAJA PENDERITA HIPERTENSI DI SMAN 10 SEMARANG
}

\author{
THE EFFECT OF GIVING AEROBIC SPORTS ACTIVITIES TO DECREASING BLOOD PRESSURE IN YOUTH \\ HYPERTENSION PATIENTS IN SMAN 10 SEMARANG
}

\author{
Isna Ma'rufiani Dewi ${ }^{1}$; Astidio Noviardhi ${ }^{2}$; Setyo Prihatin²; Susi Tursilowati²;Ana Yuliah Rahmawati
}

\begin{abstract}
Background : Hypertension in children and adolescents can be defined as Systolic Blood Pressure (TDS) / Diastolic Blood Pressure (TDD) on repeated measurements obtained from values above 95 percentiles. The incidence of hypertension in Riskesdas 2013 data for the age group 15-17 years is 5.3\%. The prevalence of hypertension in adolescents in the province of Central Java in the 2013 Riskesdas data was 12.8\%. Prevention of increasing the value of hypertension prevalence in adolescents can be done with aerobic exercise activities such as jogging.
\end{abstract}

Objective: To determine the effect of giving aerobic exercise activities to changes in blood pressure in adolescents with hypertension.

Method: Thistype of research is experimental with Randomized Control Trial Group Design. Sampling was done randomly to get 18 treatment subjects and 18 control subjects. Data collected were age, sex, weight, height, sodium intake, level of physical activity, blood pressure before and after treatment. Test the independent $t$-test wasused for data differences in blood pressure before and after treatment in both groups and paired t-test to determine changes in blood pressure before and after treatment, whereas the test ANOVA repeated measured is used to determine the effect of aerobic exercise (jogging)on blood pressure sample.

Results: There were differences in systolic and diastolic blood pressure between the treatment and control groups ( $p<0.05$ ). There is an effect of giving aerobic exercise activities to decrease systolic and diastolic blood pressure $(p=0,000$ and $p=0.003)$ for each measurement at each meeting.

Conclusion: The provision of aerobic exercise activities affects the decrease in diastolic systolic blood pressure in adolescents with hypertension.

Keywords:Adolescent, Hypertension, Aerobic Sports, Jogging

\section{ABSTRAK}

Latar Belakang : Hipertensi pada anak dan remaja dapat didefinisikan sebagai Tekanan Darah Sistolik (TDS) / Tekanan Darah Diastolik (TDD) pada pengukuran berulang yang didapat dari nilai diatas 95 persentil. Angka kejadian hipertensi di Indonesia data Riskesdas 2013 untuk golongan usia 15-17 tahun sebesar 5,3\%. Prevalensi hipertensi pada remaja di provinsi Jawa Tengah pada data Riskesdas 2013 sebesar 12,8\%. Pencegahan meningkatnya nilai prevalensi hipertensi pada remaja bisa dilakukan dengan kegiatan olahraga aerobik seperti jogging.

Tujuan : Untuk mengetahui pengaruh pemberian kegiatan olahraga aerobik terhadap perubahan tekanan darah pada remaja penderita hipertensi.

Metode : Jenis penelitian ini adalah ekperimental dengan rancangan Randomized Control Trial Group Design. Pengambilan sampel dilakukan secara acak untuk mendapatkan 18 subyek perlakuan dan 18 subyek kontrol. Data yang dikumpulkan yaitu usia, jenis kelamin, berat badan, tinggi badan, asupan natrium, tingkat aktivitas fisik, tekanan darah sebelum dan sesudah perlakuan. Uji independent $t$-test digunakan untuk perbedaan data tekanan darah sebelum dan sesudah perlakuan dari kedua kelompok dan paired t-test untuk mengetahui perubahan tekanan darah sebelum dan sesudah perlakuan, sedangkan uji anova repeated measured digunakan untuk melihat pengaruh olahraga aerobik (jogging) terhadap tekanan darah sampel. 
Hasil :Ada perbedaan tekanan darah sistolik dan diastolik antara kelompok perlakuan dan kelompok kontrol $(p<0,05)$. Ada pengaruh pemberian kegiatan olahraga aerobik terhadap penurunan tekanan darah sistolik dan diastolik ( $p=0,000$ dan $p=0,003$ ) setiap pengukuran pada setiap pertemuan.

Kesimpulan Pemberian kegiatan olahraga aerobik berpengaruh terhadap penurunan tekanan darah sistolik diastolik pada remaja penderita hipertensi.

Kata kunci : Remaja, Hipertensi, Olahraga Aerobik, Jogging

\section{PENDAHULUAN}

Hipertensi merupakan salah satu faktor risiko penyakit jantung koroner padausia dewasa, adanya hipertensi pada anak dapat menjadi awal mulaperkembangan penyakit jantung coroner pada usia dewasa kelak. ${ }^{1}$ Hipertensi adalah peningkatan tekanan darah yang memberikan gejala yang berlanjut untuk suatu target organ yaitu stroke (untuk otak), penyakit jantung koroner (untuk pembuluh darah), dengan target pada otak yang berupa stroke, hipertensi yaitu penyebab utama stroke yang membawa kematian tinggi. ${ }^{2}$

Penelitian yang dilakukan di Amerika tahun 2013, menunjukan peningkatan prevalensi hipertensi pada golongan usia 6-17 tahun dalam 30 tahun terakhir yaitu dari 7,6-10,8 \% menjadi 13-14 $\%{ }^{3} \quad$ Penelitian tentang peningkatan prevalensi hipertensi pada golongan usia 6-17 tahun juga dilakukan di negara yang lain. Penelitian di Rusia sebesar $10 \%$, di Cina sebesar 3,4\% dan di Inggris sebesar $10-17 \%{ }^{4}$

Penelitian yang dilakukan di Amerika tahun 2013, menunjukan peningkatan prevalensi hipertensi pada golongan usia 6-17 tahun dalam 30 tahun terakhir yaitu dari 7,6-10,8 \% menjadi 13-14 $\% .{ }^{5}$ Kasus hipertensi di Indonesia pada kelompok usia 15-17 tahun sebesar 5,3\% (laki-laki 6,0\% dan perempuan $4,7 \%)$, di pedesaan $(5,6 \%)$ lebih tinggi dari perkotaan (5,1\%). Di provinsi Jawa Tengah, prevalensi hipertensi sebanyak 26,4\%, sedangkan prevalensi hipertensi pada remaja sebanyak $12,8 \%$. 6

Penelitian Mintarsih (2015) mengenai Determinan Hipertensi Pada Remaja, hasil skrinning awal yang dilakukan di 3 SMAN kota Semarang tersebut, prevalensi hipertensi pada siswa/siswi terbanyak terdapat di SMAN 10 Semarang yaitu $50,8 \% .{ }^{7}$ Berdasarkan penelitian yang dilakukan Ramadhani (2016) menunjukan bahwa prevalensi hipertensi pada siswa/siswi SMAN 10 Semarang yaitu sebanyak 105 orang $(22,7 \%)$ dari 465 orang yang telah diskrining. ${ }^{8}$

Hipertensi pada anak dan remaja dapat didefinisikan sebagai Tekanan Darah Sistolik (TDS) / Tekanan Darah Diastolik (TDD) pada pengukuran berulang yang didapat dari nilai diatas 95 persentil. TDS diantara 90 dan 95 persentil dapat dikategorikan menurut JNC 7 sebagai prehipertensi dan dapat diindikasikan sebagai faktor perubahan gaya hidup pada remaja. ${ }^{9}$

Faktor resiko terjadinya hipertensi terdiri dari faktor risiko yang tidak dapat diubah (seperti keturunan atau genetik, jenis kelamin, dan umur) dan faktor risiko yang dapat diubah (seperti obesitas, kurang olahraga atau aktivitas fisik, merokok, stress, konsumsi alcohol dan konsumsi garam). ${ }^{10}$

Olahraga banyak dihubungkan dengan pengelolaan hipertensi, karena olahraga teratur dapat menurunkan ketahanan perifer yang akan menurunkan tekanan darah. Aliran darah sangat tergantung dari pembuluh darah, jika pembuluhnya mengecil tekanannya akan meningkat, sebaliknya jika pembuluh melebar maka tekanan akan turun. Salah satu hasil latihan fisik yang teratur adalah pelebaran pembuluh darah sehingga tekanan darah akan menurun. ${ }^{11}$

Salah satu jenis olahraga yang dapat menurunkan tekanan darah adalah olahraga aerobik yang meliputi senam aerobik dan jogging. Keuntungan dari latihan fisik pada senam aerobik selama 50 menit 3 kali seminggu yang dapat mengendalikan tekanan darah. Untuk mengurangi resiko hipertensi dan penyakit jantung koroner serta untuk meningkatkan kapasitas kerja fisik, Akademi Kedokteran Olahraga Amerika (The American College of Sport Medicine) merekomendasikan agar seseorang ikut serta dalam kegiatan olahraga aerobik minimum 3 kali seminggu selama 20 sampai 60 menit. $^{12}$

Tujuan penelitian ini untuk menganalisis pengaruh kegiatan olahraga aerobik (jogging) terhadap penurunan tekanan darah pada remaja penderita hipertensi.

\section{METODE}

Untuk mencapai tujuan dilakukan penelitian dengan menggunakan Eksperimental Kontrol Random (Randomized Controlled Trial). Pada penelitian ini, subyek penelitian yang memenuhi ktiteria inklusi dikelompokan menjadi 2, yaitu kelompok perlakuan dan kelompok kontrol. Kelompok perlakuan diberikan kegiatan olahraga aerobik (jogging) sebanyak 6 kali selama 2 minggu 
sedangkan untuk kelompok kontrol tidak diberikan kegiatan.

Penelitian dilakukan pada siswa/siswi kelas XI di SMAN 10 Semarang yang terdiri 36 orang dan dilakukan selama 14 hari (30 April sampai 14 Mei 2018). Subyek penelitian ini adalah siswa/siswi yang setelah dilakukan skrining dengan 3 kali pengukuran dinyatakan memiliki tekanan darah tinggi, tidak merokok bersedia berperan serta dalam penelitian, memiliki tekanan darah sistolik dan diastolik $\geq 99$ persentil.

Kelompok perlakuan dalam penelitian ini diberi kegiatan olahraga aerobik (jogging) sebanyak 6 kali selama 2 minggu. Selama kegiatan berlangsung subyek penelitian akan difasilitasi tempat dan pelatih yang kompeten dalam bidang olahraga, sedangkan kelompok kontrol tidak diberi kegiatan olahraga aerobik. Variabel dependent yaitu tekanan darah pada remaja penderita hipertensi yang diukur pada sebelum dan sesudah intervensi menggunakan tensimester digital. Variabel independent yaitu pemberian kegiatan olahraga aerobik (jogging).

Instrumen yang digunakan terdiri dari formulir skrining, formulir ketesediaan menjadi subyek penelitian, formulir identitas sampel, formulir pengecekan tekanan darah, formulir aktivitas fisik 24 jam dan formulir Semi Quantitative Frequency Questioner (SQ-FFQ). Penentuan status gizi dari hasil pengukuran BB yang diukur menggunakan timbangan digital dan TB yang diukur menggunakan microtoice. Data aktivitas fisik diketahui melalui formulir kegiatan aktivitas selama 24 jam yang diisi oleh subyek penelitian kemudian dilakukan perhitungan oleh peneliti. Data asupan natrium yang diperoleh dengan cara subyek penelitian mengisi formulir Semi Quantitative Frequency Questioner (SQ-FFQ). Data tekanan darah diukur menggunakan tensimeter digital saat sebelum dan sesudah intervensi.

Analisis univariat digunakan untuk mengetahui distribusi frekuensi subyek penelitian dengan tekanan darah tinggi, jenis kelamin, status gizi, asupan natrium dan aktivitas fisisk. Analisis bivariat digunakan untuk mengetahui perbedaan tekanan darah antara kelompok perlakuan dan kelompok kontrol dengan uji Independent t-test tingkat kemaknaan $\alpha \quad 0,05$ dan mengetahui perubahan tekanan darah sebelum dan sesudah perlakuan antara kelompok perlakuan dan kelompok kontrol dengan uji Paired t-test tingkat kemaknaan $\alpha$ 0,05. Analisis multivariat menggunakan uji Anova Reapeted Measure dengan tingkat kemaknaan $\alpha 0,05$.

\section{HASIL PENELITIAN}

Penelitian ini dilakukan di siswa/siswi kelas XI SMAN 10 Semarang sebanyak 36 siswa/siswi selama 14 hari (30 April-14 Mei 2018). Jumlah subyek penelitian 36 siswa/siswi, dengan rincian masing-masing 18 siswa/siswi di tiap kelompok.

\section{Karakteristik Subjek Penelitian}

Karakteristik subyek menurut jenis
kelamin diketahui dengan melakukan
wawancara langsung dan mengisi formulir
identitas subyek penelitian. Untuk karakteristik
subyek penelitian menurut tingkat aktivitas fisik
diketahui dengan cara melakukan pengisian
formulir aktivitas fisik selama 24 jam. Untuk
karakteristik subyek penelitian menurut asupan
natrium diketahui dengan cara melakukan
pengisian formulir Semi Quantitative Frequency
Questioner (SQ-FFQ) oleh subyek kemudian
dilakukan perhitungan oleh peneliti. Untuk
karakteristik subjek penelitian menurut status
gizi diketahui dengan cara melakukan
penimbangan berat badan dan pengukuran
tinggi badan secara langsung. Penimbangan
berat badan yang dilakukan dengan timbangan
digital merk GEA dengan ketelitian 0,01 kg dan
pengukuran tinggi badan menggunakan
microtoise dengan ketelitian 0,1 cm. Setelah
memperoleh data berat badan dan tinggi badan
kemudian dihitung IMT dengan satuan kg/m2
untuk menentukan status gizi. Selanjutnya data
status gizi diklasifikasikan berdasarkan IMT
menurut WHO (2005). Kemudian karakteritik
subyek penelitian menurut kategori persentil
tekanan darah dilakukan dengan tensimeter
digital merk OMRON dengan akurasi
pengukuran pabrik OMRON adalah \pm 3 mmHg,
dalam $\pm 5 \%$ dari pembacaan denyut nadi. Hasil
analisis dapat dilihat pada tabel 1.

Tabel 1. Karakteristik subjek penelitian 


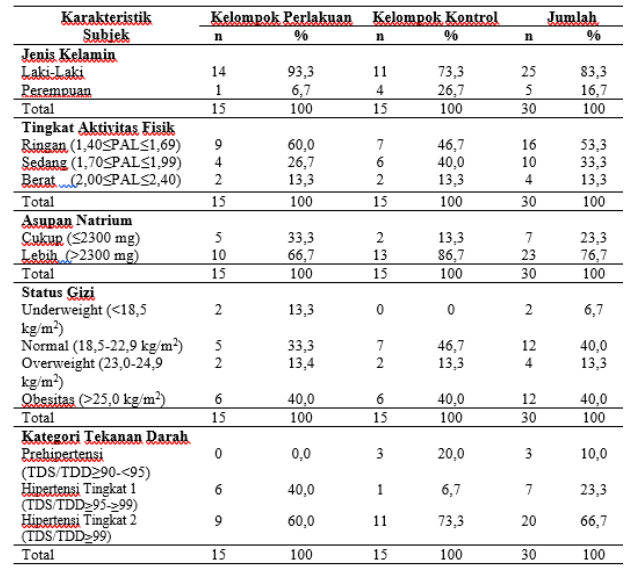

2. Persentil tekanan darah sistolik dan diastolik sesudah pemberian kegiatan olahraga aerobik antara kelompok perlakuan dengan kelompok control

Analisis persentil tekanan darah sistolik dan diastolik sesudah pemberian kegiatan olahraga aerobik antara kelompok perlakuan dan kelompok kontrol menggunakan uji Independent $t$-test. Hasil analisis menunjukan ada perbedaan yang signifikan $(p<0,05)$.

Tabel 2. Persentil Tekanan Darah Sistolik dan diastolik Seseudah Perlakuan

\begin{tabular}{lccc}
\hline \multirow{2}{*}{$\begin{array}{c}\text { Tekanan } \\
\text { Darah }\end{array}$} & Rerlakuan $(\mathbf{n}=15)$ & Kontrol $(\mathbf{n}=15)$ & \multirow{2}{*}{$\mathbf{p}$} \\
\cline { 2 - 3 } & Mean \pm SD & Mean \pm SD & \\
\hline Sistolik Akhir & $63,67 \pm 20,042$ & $96,40 \pm 3,680$ & 0,00 \\
Diastolik Akhir & $85,27 \pm 14,504$ & $96,93 \pm 3,731$ & 0,05 \\
\hline
\end{tabular}

3. Persentil Tekanan Darah Sistolik Sebelum dan Sesudah Pemberian Kegiatan Olahraga antara Kelompok Perlakuan dengan Kelompok Kontrol

Analisis persentil tekanan darah sistolik sebelum dan sesudah pemberian kegiatan olahraga aerobik antara kelompok perlakuan dan kelompok kontrol menggunakan uji Paired $t$-test. Hasil analisis menunjukan ada perbedaan signifikan $(p<0,05)$.

Tabel 3. Persentil Tekanan Darah Sistolik Sebelum dan Sesudah Pemberian Kegiatan Olahraga Aerobik

\begin{tabular}{lcccc}
\hline \multirow{2}{*}{$\begin{array}{c}\text { Persentil } \\
\text { TDS }\end{array}$} & \multicolumn{2}{c}{ Perlakuan $(\mathbf{n}=\mathbf{1 5})$} & \multicolumn{3}{c}{ Kontrol $(\mathbf{n}=\mathbf{1 5})$} \\
\cline { 2 - 5 } & Rata-rata & $\mathbf{p}$ & Rata-rata & $\mathbf{p}$ \\
\hline Sebelum & $97,40 \pm 2,028$ & & $96,93 \pm 3,731$ & \multirow{2}{*}{0,164} \\
Sesudah & $63,67 \pm 20,042$ & 0,000 & $96,40 \pm 3,680$ & \\
\hline
\end{tabular}

4. Persentil tekanan darah diastolik sebelum dan sesudah pemberian kegiatan olahraga antara kelompok perlakuan dengan kelompok kontrol

Analisi persentil tekanan darah diastolik sebelum dan sesudah pemberian kegiatan olahraga aerobik antara kelompok perlakuan dan kelompok kontrol menggunakan uji Paired t-test. Hasil analisis menunjukan ada perbedaan signifikan $(p<0,05)$.

Tabel 4. Persentil tekanan darah diastolik sebelum dan sesudah pemberian kegiatan olahraga aerobik

\begin{tabular}{lcccc}
\hline \multirow{2}{*}{$\begin{array}{c}\text { Persentil } \\
\text { TDD }\end{array}$} & Perlakuan $(\mathbf{n}=\mathbf{1 5})$ & \multicolumn{3}{c}{ Kontrol $(\mathbf{n}=\mathbf{1 5})$} \\
\cline { 2 - 5 } & Rata-rata & $\mathbf{p}$ & Rata-rata & $\mathbf{p}$ \\
\hline Sebelum & $96,93 \pm 3,731$ & 0,009 & $88,07 \pm 15,908$ & \\
Sesudah & $85,27 \pm 14,504$ & & $96,93 \pm 3,731$ & 0,072 \\
\hline
\end{tabular}

5. Tekanan Darah Sistolik dan Diastolik Selama Pemberian Kegiatan Olaharaga Aerobik

Analisis multivariat dilakukan untuk mengetahui perbedaan tekanan darah sitolik dan diastolik pengukuran ke-1, ke-2, ke-3, ke-4, ke-5 dan ke- 6 pada kelompok perlakuan dan kelompok kontrol. Analisis menggunakan uji Anova Repeated Measure. Adapun hasil uji Anova Repeated Measure dapat dilihat pada tabel 5.

Tabel 5. Tekanan Darah Sistolik dan Diastolik selama Penelitian

\begin{tabular}{lccl}
\hline \multirow{2}{*}{ Tekanan Darah } & Perlakuan & Kontrol & \multirow{2}{*}{ p } \\
\cline { 2 - 3 } & Mean \pm SD & Mean \pm SD & \\
\hline Sistolik 1 & $97,40 \pm 2,028$ & $96,93 \pm 3,731$ & \\
Sistolik 2 & $88,93 \pm 11,145$ & $97,40 \pm 2,028$ & \\
Sistolik 3 & $87,67 \pm 10,499$ & $95,67 \pm 2,968$ & \\
Sistolik 4 & $83,00 \pm 17,196$ & $92,27 \pm \pm 3,035$ & 0,000 \\
Sistolik 5 & $76,67 \pm 19,518$ & $95,67 \pm 2,968$ & \\
Sistolik 6 & $63,33 \pm 19,518$ & $96,40 \pm 3,680$ & \\
\hline Diastolik 1 & $96,93 \pm 3,731$ & $88,07 \pm 15,908$ & \\
Diastolik 2 & $96,13 \pm 3,623$ & $97,93 \pm 1,831$ & \\
Diastolik 3 & $91,87 \pm 17,154$ & $98,13 \pm 2,475$ & \\
Diastolik 4 & $90,80 \pm 16,772$ & $99,00 \pm 0,000$ & 0,003 \\
Diastolik 5 & $90,27 \pm 11,511$ & $98,47 \pm 1,407$ & \\
Diastolik 6 & $82,00 \pm 16,562$ & $96,93 \pm 3,731$ & \\
\hline
\end{tabular}

\section{PEMBAHASAN}

\section{Karaktersitik Subyek Penelitian}

Subjek penelitian terbanyak yaitu berjenis kelamin laki-laki sebesar 83,3\%, diketahui bahwa jenis kelamin merupakan salah 
satu faktor yang mempengaruhi tekanan darah. ${ }^{13}$ Tekanan darah pada remaja laki-laki lebih tinggi dibandingkan dengan tekanan darah remaja perempuan. Dalam penelitian Fitriana (2012) pada murid SMP di Minnesota, Minneapolis, ditemukan secara signifikan tekanan darah remaja laki - laki lebih tinggi dibanding perempuan. ${ }^{14}$ Dalam penelitian Harris (2009), tekanan darah remaja laki-laki tinggi karena berkaitan dengan obesitas pada laki-laki, laki-laki obesitas cenderung mempunyai deposit lemak di daerah atas tubuh khususnya pada tengkuk, leher, bahu dan perut yang disebut obesitas tipe android, pada obesitas terjadi resitensi insulin dan gangguan fungsi endotel pembuluh darah yang menyebabkan vasokonstriksi dan reabsosrbsi natrium di ginjal yang mengakibatkan hipertensi. ${ }^{15,16}$

Subyek penelitian sebagian besar menderita hipertensi dalam kategori hipertensi tingkat 2 . Hipertensi tingkat 2 yaitu apabila hasil pemeriksaan berada pada persentil 99 atau lebih. Selama penelitian perubahan tekanan darah pada setiap kelompok subjek penelitian yaitu kelompok perlakuan yang mengalami penurunan tekanan darah $(93,3 \%)$ sedangkan untuk kelompok kontrol yang mengalami penurunan tekanan darah $(53,4 \%) .{ }^{17}$

2. Persentil tekanan darah sistolik dan diastolik sesudah pemberian kegiatan olahraga aerobik antara kelompok perlakuan dengan kelompok control

Berdasarkan tabel 2 diperoleh ada perbedaan signifikan pada persentil tekanan darah sistolik dan persentil tekanan darah diastolik antara kelompok perlakuan dengan kelompok kontrol setelah dilakukan perlakuan kegiatan olahraga aerobik (jogging) sebanyak 6 kali. Nilai persentil tekanan darah sistolik diakhir kegiatan pada kelompok perlakuan yaitu tekanan darah kelompok perlakuan masuk dalam kategori normal karena nilai persentil kurang dari 90 (Mean \pm SD $=63,67 \pm 20,042$ ), sedangkan persentil tekanan darah sistolik diakhir kegiatan pada kelompok kontrol yaitu tekanan darah kelompok kontrol masuk dalam kategori Hipertensi tingkat 1 karena nilai persentil nilai persentil sistolik lebih dari 95 sampai dengan 99 (Mean $\pm S D=96,40 \pm 3,680$ ). Nilai persentil tekanan darah diastolik diakhir kegiatan pada kelompok perlakuan yaitu tekanan darah kelompok perlakuan masuk dalam kategori normal karena nilai persentil kurang dari 90 (Mean $\pm S D=85,27 \pm 14,504)$, sedangkan persentil tekanan darah diastolik diakhir kegiatan pada kelompok kontrol yaitu tekanan darah kelompok kontrol masuk dalam kategori Hipertensi tingkat 1 karena nilai persentil nilai persentil sistolik lebih dari 95 sampai dengan 99 (Mean $\pm S D=96,93 \pm 3,731$ )

Hasil pada tabel 2, menjelaskan ada perbedaan nilai persentil sistolik dan diastolik setelah dilakukan kegiatan olahraga aerobik (jogging). Selama olahraga aerobik (jogging) akan terjadi kontrol terintegrasi pada tekanan darah. Tekanan dikendalikan secara reflex melalui sistem saraf otonom, khususnya sensor khusus yang berlokasi di aortic arch dan arteri carotid, yang disebut reflux baroreseptor. Baroreseptor sangat sensitive untuk mengubah tekanan arteri. Refleks baroreseptor berfungsi sebagai penahan (pengontrol) pada perubahan tekanan darah. Meningkatnya hormon epinefrin saat olahraga menyebabkan semakin kuatnya kontraksi otot jantung. Meskipun demikian, tekanan sistolik tidak langsung membumbung tinggi karena pengaruh epinefrin pada pembuluh darah yang dapat menyebabkan dilatasi (pelebaran). Pelebaran pembuluh darah akan sangat tergantung kondisi pembuluh darah. Peningkatan signifikan tekanan sistolik dan nadi, disebabkan oleh ajeksi darah oleh bilik kiri secara lebih cepat dan kuat, yang menyebabkan suatu peningkatan rata-rata tekanan darah arterial. ${ }^{18}$

3. Persentil tekanan darah sistolik sebelum dan sesudah pemberian kegiatan olahraga antara kelompok perlakuan dengan kelompok kontrol

Pada tabel 3, hasil statistik menunjukan ada perbedaan yang bermakna $(p<0,05)$ pada penurunan nilai persentil tekanan darah sistolik sebelum dan sesudah pemberian kegiatan olahraga aerobik. Rata-rata penurunan nilai persentil tekanan darah sistolik kelompok perlakuan 33,73 dibandingkan kelompok kontrol yang mengalami penurunan tekanan darah sistolik 0,53. Artinya ada pengaruh kegiatan olahraga aerobik terhadap tekanan darah sistolik.

Hasil pada tabel 3, menjelaskan bahwa ada pengaruh kegiatan olahraga aerobik (jogging) dengan perbedaan nilai persentil tekanan darah sistolik pada kelompok perlakuan $(p=0,000)$ sedangkan pada kelompok kontrol menunjukan tidak ada pengaruh $(p=0,164)$, hal ini terjadi karena yang mendapat perlakuan kegiatan olahraga aerobik (jogging) hanya pada kelompok perlakuan. 
Hipertensi atau tekanan darah tinggi yaitu apabila sistem kompleks yang mengatur tekanan darah tidak berjalan sesuai dengan semestinya, terjadi peningkatan tekanan dalam arteri yang terjadi secara terus-menerus dan menetap. Setiap denyut jantung merupakan satu periode yang memiliki 2 fase yaitu sistolik dan diastolik. Sistolik adalah fase kontraksi yaitu fase darah yang sedang dipompa oleh denyut jantung. Diastolik adalah fase istirahat yaitu menunjukan fase darah kembali ke dalam jantung. ${ }^{19}$

Penelitian ini sejalan dengan Fitri (2016) mendapatkan hasil ada pengaruh pemberian latihan fisik terhadap tekanan darah. Penelitian ini menunjukan bahwa penurunan tekanan darah sistolik sebesar 16,20 mmHg dan penurunan tekanan darah diastolik sebesar $16,40 \mathrm{mmHg}$. Kegiatan olahraga yang dilakukan adalah senam aerobik selama 2 minggu. ${ }^{20}$

\section{Persentil tekanan darah diastolik sebelum dan sesudah pemberian kegiatan olahraga antara kelompok perlakuan dengan kelompok kontrol}

Hasil pada tabel diatas, menjelaskan bahwa ada pengaruh kegiatan olahraga aerobik (jogging) dengan perbedaan nilai persentil tekanan darah diastolik pada kelompok perlakuan $(p=0,009)$ sedangkan pada kelompok kontrol menunjukan tidak ada pengaruh $(p=0,072)$, hal ini terjadi karena yang mendapat perlakuan kegiatan olahraga aerobik (jogging) hanya pada kelompok perlakuan.

Didukung juga oleh penelitian yang dilakukan oleh Syatria (2006) tentang pengaruh olahraga terprogram terhadap tekanan darah menujukkan terjadinya perbedaan terhadap kelompok perlakuan, bahwa olahraga terprogram menyebabkan penurunan tekanan sistolik yang bermakna dan penurunan tekanan diastolik bermakna dengan nilai $p$ value $0,022 .{ }^{21}$ Penelitian ini sejalan dengan Rismayanti (2008) mendapatkan hasil ada hubungan antara olahraga dengan penurunan risiko hipertensi. Penelitian ini menunjukan bahwa penurunan tekanan darah sebesar 5 $\mathrm{mmHg}$ akan menyebabkan penurunan kejadian stroke sebesar $40 \%$ dan penurunan kejadian infark miokard sebanyak $15 \%$ pada subjek hipertensi yang telah mengalami penurunan tekanan darah. ${ }^{22}$

5. Tekanan darah sistolik dan diastolik selama pemberian kegiatan olaharaga aerobik dengan faktor pengganggu asupan natrium, tingkat aktivitas fisik dan status gizi
Dari uji statistik didapatkan untuk penurunan tekanan darah sistolik dan diastolik selama penelitian. Pada tabel 5, dapat disimpulkan secara statistik bahwa ada perbedaan pada tekanan darah sistolik $(p=$ $0,000)$ dan diastolik $(p=0,003)$ selama 6 kali pengukuran dengan variabel pengganggu berupa asupan natrium, tingkat aktivitas fisik dan status gizi. Dari hasil analisis dapat disimpulkan ada pengaruh pemberian kegiatan olahraga aerobik terhadap penurunan tekanan darah sistolik dan diastolik.

Latihan fisik atau olahraga yang teratur dapat meningkatkan kesehatan jasmani dna rohani secara menyeluruh. Metabolisme tubuh akan membaik dari segi fisik dan mental. Peningkatan pada sistem tubuh selama tingginya berolahraga. Karena aliran darah lebih banyak dibutuhkan selama berolahraga, tubuh akan secara otomatis menurunkan tingkat ketahanan terhadap aliran darah didalam pembuluh darah selama melakukan olahraga untuk memenuhi kebutuhan dengan begitu tekanan sistolik akan turun dengan melakukan olahraga. ${ }^{23}$

Agar darah secara efisien terkirim ke otot-otot pada saat melakukan olahraga, ketahan dalam pembuluh darah harus diturunkan. Ketika intensitas olahraga meningkat pembuluh nadi tubuh melebar memungkinkan lebih banyak aliran yang tidak terhalang ke otot-otot aktif. Selain pelebaran pembuluh nadi ke otot-otot yang bekerja, aliran pembuluh nadi ke jaringan tidak aktif lainnya dalam tubuh juga diturunkan atau dijauhkandari aliran darah ekstra yang tidak dilakukan pada saat itu. Proses ini dicapai dengan kontraksi tak sadar otot polos dalam pembuluh darah. Peningkatan kontraksi otot polos mengakibatkan penurunan aliran darah melalui kontraksi. Jumlah total ketahanan atau resistensi perifer total (total peripheral resistencel/TPR) kealiran darah biasanya turun selama melakukan olahraga. ${ }^{24}$

\section{DAFTAR PUSTAKA}

1. Supartha M, Suarta IK, Winaya, A IB. Hipertensi Pada Anak. Majalah Kedokteran Indonesia. 2009;221-30.

2. WHO. A global brief on Hypertension. 2013;10-1.

3. Destiany V, Sulchan M. Asupan Tinggi Natrium dan Lama Menonton TV Sebagai Faktor Risiko Hipertensi Obesitik pada Remaja Awal. J Nutr Coll. 2013;2:111-7. 
4. Kementrian Kesehatan RI. Riset Kesehatan Dasar 2013. 2013.

5. Mintarsih SN, Supadi J, Jaelani M. Determinan Hipertensi pada Remaja. Jur Gizi Politek Kesehat Semarang. 2015;

6. Ramadhani F. Pengaruh Pemberian Buah Pisang Ambon Terhadap Tekanan Darah Sistolik dan Diastolik pada Penderita Hipertensi Remaja di SMAN 10 Semarang. Perpust Gizi Politek Kesehat Kemenkes Semarang. 2017;

7. Ismanto I, Rahmawati T. Hubungan Olahraga Terhadap Tekanan Darah Penderita Hipertensi Rawat Jalan di Rumah Sakit PKU Muhammadiyah Surakarta. 2014.

8. Silva DAS, Teixeira DM, Oliveira G De, Petroski EL, Farias JM De. Aerobic Fitnes in Adolescents in Southern Brazil: Association with Sociodemographic Aspects, Lifestyle and Nutritional Status. Rev Andaluza Med del Deport [Internet]. 2016;9(1):17-22. Available from:

http://dx.doi.org/10.1016/j.ramd.2014.11.00 2

9. Phillips SM, Bandini LG, Naumova EN, Cyr H, Colclough S, Dietz WH, et al. Energy-Dense Snack Food Intake in Adolescence: Longitudinal Relationship to Weight and Fatness. Obes Res [Internet]. 2004;12(3):461$72 . \quad$ Available from: http://doi.wiley.com/10.1038/oby.2004.52

10. Fitriana R, Lipoeto $\mathrm{N}$, Triana V. Faktor risiko kejadian hipertensi pada remaja di wilayah kerja Puskesmas Rawat Inap Sidomulyo Kota Pekanbaru. J Kesehat Masy Andalas [Internet]. 2012;7(1):10-5. Available from: http://jurnal.fkm.unand.ac.id/index.php/jkm a/article/view/101

11. Gidding SS, Dennison BA, Birch LL, Daniels SR, Gilman MW, Lichtenstein $A H$, et al. Dietary recommendations for children and adolescents: A guide for practitioners consensus statement from the American Heart Association. Circulation. 2005;112(13):2061-75.

12. Giriwijoyo S. Olahraga dan Kesehatan. Bandung: FPOK-UPI; 2005.

13. Widyaningtyas $\mathrm{UH}$. The Influence Of Hypertention Gymnastics Toward the Blood Pressure to Hypertensive Elederly Patients in Dharma Bhakti Elderly House Surakarta Working Areas. 2016;

14. Prativi G, Soegiyanto, Sutardji. Pengaruh Aktivitas Olahraga terhadap Kebugaran Jasmani. J Sport Sci Fit. 2012;1(1):56-61.

15. Jaelani, M., Larasati, M. D., Rahmawati, A. Y., \& Ambarwati, R. (2018). Efektifitas Aktivitas
Peer Group terhadap Penurunan Berat Badan dan Persen Lemak Tubuh pada Remaja Overweight. Jurnal Kedokteran Brawijaya, 30(2), 127-132.

16. Putriastuti L. Analisis Hubungan Antara Kebiasaan Olahraga Dengan Kejadian Hipertensi Pada Pasien Usia 45 Tahun Keatas. J Berk Epidemiol. 2016;4 nomor 2(July 2016):225-36.

17. Putri G, Mulyani S, Agung A. Efektivitas Senam Jantung Sehat terhadap Penurunan Tekanan Darah pada Penderita Hipertensi. Aceh Nutr J. 2016;

18. Sulistyoningsih H. Gizi Untuk Kesehatan Ibu dan Anak. Yogyakarta: Graha Ilmu; 2011.

19. Al-Mighwar M. Psikologi Remaja. Bandung: Pustaka Setia; 2011. 87-88 p.

20. Hurlock. Psikologi Perkembangan. Indonesia: Erlangga; 2003.

21. Rusdi. Awas! Bisa mati cepat akibat Hipertensi dan Diabetes. Jogjakarta: Power Books (IHDINA); 2009.

22. Santoso D. Membonsai Hipertensi. Surabaya: Jaring Pena; 2010. 35 p.

23. MEDICALOGY. Metode Pengukuran Tekanan Darah [Internet]. MEDICALOGY TEAM. [cited 2018 Mar 20]. p. ALAT-ALAT KESEHATAN. Available from: https://www.medicalogy.com/blog/tensimet er-konvensional-vs-tensimeter-digital/

24. Manembu M, Rumampuk J, Danes VR. Pengaruh posisi duduk dan berdiri terhadap tekanan darah sistolik dan diastolik pada pegawai negeri sipilkabupaten minahasa utara 2. J e-Biomedik. 2015;3(3):814-20 